\title{
Organic-Polymeric Radial Flow Biorreactor for Liver Models
}

\author{
O. Ramírez-Fernández ${ }^{1 *}$, E. Zúñiga-Aguilar ${ }^{2}$, L.E. Gómez-Quiroz ${ }^{3}$, M.C. Gutiérrez-Ruiž ${ }^{3}$,
} R. Godinez ${ }^{2}$

${ }^{1}$ UNITEC

${ }^{2}$ Departamento de Ingeniería Eléctrica. Universidad Autónoma Metropolitana, Unidad Iztapalapa, Apdo. Postal 55-534, Iztapalapa, México, D.F.

${ }^{3}$ Departamento de Ciencias de la Salud. Universidad Autónoma Metropolitana, Unidad Iztapalapa, Apdo. Postal 55-534, Iztapalapa, México, D.F.

\section{ABSTRACT}

An artificial liver support system is based on the functional hepatocytes being cultured inside a bioreactor; this technique has being used as an effective therapy for treating chronic liver diseases in recent times. This work evaluates different parameters such as cell viability and metabolic function of the hepatocytes when cultured on a hybrid scaffold. The scaffold was built using a polypyrrole plasma coated polymer layer seeded with endothelial matrix for efficient three-dimensional hepatocyte growth within a radial flow bioreactor. The flow rate inside the bioreactor was $7 \mathrm{ml} / \mathrm{min}$. The parts for the bioreactor where either built using food-grade steel and/or glass or the scaffolds comprise a Poly (L-lactic acid)-coated polypyrrole iodine layer or not for HepG2 culture. The results show that the Poly (L-lactic acid)-coated scaffolds increased cell proliferation by $30 \%$, protein production by $16 \%$ and albumin secretion by $40 \%$ compared with the non-coated scaffold. All experiments were performed thrice and data was analysed by ANOVA and Tukey statistic models with a $\mathrm{p}<0.05$. The obtained results demonstrated that radial flow bioreactors in conjunction with hybrid scaffolds improve hepatocytes' physiological and functional properties and could be used as an alternative therapy for patients with liver diseases.

Keywords: hepatocytes, glow discharge polymerization, polypyrrole, PLLA, HUVEC, biorreactor.

Correspondencia:

Odin Ramírez-Fernández

Departamento de Ingeniería Eléctrica, Universidad Autónoma Metropolitana, Unidad Iztapalapa.

Correo electrónico: odinramirezfernandez@gmail.com
Fecha de recepción: 26 de febrero de 2016

Fecha de aceptación: 30 de mayo de 2016 


\section{RESUMEN}

Un sistema de soporte hepático artificial se basa en utilizar hepatocitos funcionales cultivados en un biorreactor; esta técnica ha demostrado que se puede utilizar como una terapia eficaz para el tratamiento de enfermedades crónicas del hígado en los últimos tiempos. Este trabajo evalúa diferentes parámetros tales como la viabilidad celular y la función metabólica de los hepatocitos cuando se cultivan en un andamio híbrido. El andamio fue construido usando una capa de polímero recubierto de polipirrol plasma, se sembró con un cultivo tridimensional de células endoteliales y de hepatocitos dentro de un biorreactor de flujo radial. La velocidad de flujo en el interior del biorreactor fue de $7 \mathrm{ml} / \mathrm{min}$. Las piezas para el biorreactor fueron construidas con acero de calidad alimentaria y / o vidrio. Los andamios control fueron de ácido L-poliláctico y a estos se les agrego un revestimiento de polipirrol-yodo para el cultivo de HepG2. Los resultados muestran que el ácido L-poliláctico recubierto, aumento la proliferación celular en un 30\%, la producción de proteínas en un 16\% y la secreción de albúmina por $40 \%$ en comparación con el andamio no recubierto. Todos los experimentos se llevaron a cabo tres veces y los datos se analizaron mediante modelos estadísticos ANOVA y Tukey con una $\mathrm{p}<0.05$. Los resultados obtenidos demostraron que los biorreactores de flujo radial conjuntamente con andamios híbridos mejoran las propiedades fisiológicas y funcionales hepatocitos y podrían utilizarse como una terapia alternativa para los pacientes con enfermedades hepáticas crónicas.

Palabras clave: hepatocitos, polimerización de descarga, polypirol, PLLA, HUVEC, biorreactor.

\section{INTRODUCTION}

Liver transplantation is currently the only medical aid for patients with fulminant and/or chronic liver disease (Carpentier, 2009). Nevertheless, the waiting list for hepatic transplantation is usually long, so it is imminent to improve the actual technology to build artificial liver support systems, known as bioartificial liver (BAL) (Carpentier, 2009; McKenzie, 2008).

A BAL is used to alleviate temporary or permanently liver dysfunctions or serious liver failure (Carpentier, 2009). There are different BAL platforms that are classified according to their particular functions that include detoxification (hemodialysis, carbon-activated hemoperfusion, and plasma exchange), metabolic activity and protein synthesis, processes that are performed by hepatocytes under normal conditions. The BAL is then connected to the patient through cardiopulmonary bypass circuits to replace hepatocytes function (McKenzie, 2008).
Different kind of BAL have been constructed based on the function of primary cultured hepatocytes and have been also integrated into the extra-capillarity space of cartridges similar to those used in hemodialysis procedures (Zheng, 2013).

Today, the building of scaffolds that preserve structural function and good perfusion for successful cell adhesion and tissue morphology preservation has become a big challenge (McKenzie 2008; Wang 2010). Considerations for BAL design are cell distribution and culture media flow uniformity in order to achieve hepatocyte metabolic performance and demands when seeded on any type of scaffold (Galbusera, 2007). The limited access to primary human hepatocytes is another important limitation on BAL design that is why immortalized hepatocytes cell lines that retain metabolic capabilities are used (Pampaloni, 2007). In addition, radial volumetric supplies for liver cell bioreactors is necessary for the constant and equilibrate nutrient delivery 
that maintains hepatocytes intact for days making cartridges replacement unnecessary (Park, 2008).

Radial flow bioreactors used porous scaffolds contained in a cylindrical matrix through which media flows continuously from the periphery toward the central axis (Chen, 2008; Ishii 2008). The flow continuity through the scaffold generates oxygen and nutrients gradients decreasing the generation of stressed conditions and waste storage. The system also increases cultured cell viability for more time (Du, 2008; Li, 2009).

Polylactic acid (PLLA) is one of the most common biomaterials used for cell scaffold building, it can be easily coated to improve cell adhesion properties with no affection of its original properties (Li, 2009). Another popular biomaterial is the PLLA due its low protein adherence. PLLA chemical modifications are necessary for protein anchorage (Sachiro, 2014). Was used Polypyrrole-iodine plasma polymerization (Ppy-I) coating in our scaffolds because it is also an inert biomaterial that does not trap proteins and allows cell adherence through amines and other functional group as we previously reported (Sachiro, 2014; Cruz, 1999; Zuñiga-Aguilar, 2013; Olayo, 2008; Dhillon 2010; Ramirez-Fernandez, 2014).

The Polypyrrole plasma polymerization (Ppy) chemical diversity (primary amines, nitriles and aliphatic fragments) has been extensively studied furthermore when the Ppy is plasma-polymerized where (Zhang, 1997; Wang, 2004), there is rupture of ringlike structures that forms a low conductivity, humidity-sensitive complex polymer (Cruz, 1999). Ppy coating has been used on cell culture as in spinal cord injuries in vivo experiments (Cruz, 2012). Given its physical properties the Ppy coating does not actively interact with the cells in the culture but provides better cell anchoring that results in a higher proliferation rate, and enhanced metabolism probably due the amino $\left(-\mathrm{NH}_{2}\right)$ accumulation on the surface and other functional groups that are produced during the plasma polymerization process. (Sachiro, 2014; Cruz, 1999; ZuñigaAguilar, 2013; Olayo, 2008; Dhillon 2010; Ramirez-Fernandez, 2014, Zuñiga-Aguilar, 2014).

To achieve a more efficient tissue-like culture, hepatocytes and endothelial cells have been cocultured in different studies showing an increase in cell viability that is associated to the signaling molecules that are secreted by the endothelial cell, necessary to maintain the hepatocyte microenvironment (Ramirez-Fernandez, 2012, Thomas, 2006). Interaction between endothelial cells and hepatocytes is critical for a proper function of the liver. The liver endothelium presents open pores called fenestrae (Inamori, 2009), which facilitate the transport of nutrients and metabolites of non- parenchymal liver cells and hepatocytes (Risbud, 2003). In addition to increasing the production of certain proteins and metabolites in hepatocytes when used in co-cultures in bioreactors (RamirezFernandez, 2012; Risbud, 2003).

For BAL building it is necessary to have the cultures at higher cellular confluence owing to the need to secrete metabolite and essential proteins, such as albumin, the most abundant and important protein in the blood stream. Albumin is a protein that regulates the transport of vitamins and minerals throughout the body, regulates coagulation factors and nutrition, oncotic pressure, and executes a very important role in blood detoxification (Werner, 2000; Yamashita, 2002).

Our data confirms the beneficial interaction between hepatocytes and endothelial cells when cultured on Ppy -I coated surfaces since there was an increase of cell proliferation and more total protein secretion including the albumin when compared with non-coated scaffolds. Therefore we suggest that Ppy-I coated scaffolds co-cultures will improve BAL devices detoxification capabilities for patients 
enduring acute liver failure.

\section{MATERIALS AND METHODS}

\section{System description}

A radial flow bioreactor (RFB) comprises a cylindrical chamber (Figure 1). The chamber was built using a glass cylinder $(50 \mathrm{~mm} \times 100 \mathrm{~mm})$, containing a $6.35 \mathrm{~mm}$ foodgrade steel central support (T-304, Mask steel, México) with a $1 \mathrm{~mm}$ pit each $2 \mathrm{~mm}$ pattern displayed on the entire surface. The PLLA/Ppy-I coated scaffolds $(60 \times 25 \times 5 \mathrm{~mm})$ were placed in the main support. Once cells were seeded on the scaffolds, chamber was filled up with media to $80 \%$ of its capacity and placed inside a standard incubator $(5 \%$ $\left.\mathrm{CO}_{2}, 37^{\circ} \mathrm{C}\right)$.

Injection and radial media culture flow inside the bioreactor was achieved by a peristaltic pump and it was delivered to the glass chamber through the input. Samples from the circulation media culture were storaged at a $2^{\circ} \mathrm{C}$ for further analysis. Mechanical cutting effort applied to the scaffolds and cells, were performed to fulfill efficient cellular nutrient delivery and to avoid static areas with a zero flow inside the bioreactor, in order to preserve the culture intact. The RFB geometric model was designed by SolidWorks (Dessault systems, inc., USA) compatible with Cosmos Flowworks software (Dessault systems, inc.,USA), to determine the speed range and effort applied in the scaffold Navier-Stokes equations were used. Material and scaffold porosity (500 microns and a polyethylene sponge), edge chamber features (glass and T-304 steel) and an initial flow rate of $7 \mathrm{ml} / \mathrm{min}$ was assessed. Culture media description was settled as isothermal, Newtonian fluid, $1,000 \mathrm{~kg} / \mathrm{cm}^{3}$ density, 0.889 $\mathrm{mPa}$ kinematic viscosity and the volume shape inside the RFB.

\section{Plasma polymerization}

Poly (L-lactic acid) and (PLLA) coated scaffolds were purchased to Concordia (BIOFELT cat No. 88-0960D, USA), 25$100 \mathrm{mg} / \mathrm{cc}$ and $90 \%$ porosity. The sponges surfaces were modified with Ppy-I using plasma discharge technology under the following conditions: pyrrole monomers (98\% Sigma-Aldrich, USA) and Iodine (98\% Sigma-Aldrich, USA),13.5 MHz oscillation frequency, 50 watts (Dressler Cesar, RF Power Generator, Germany), Pirani Pressure Vacuum Sensor $9 \times 10^{-2}$ Torr (Edwards Active Gauge Controller, Germany) by 20 min alternating $6 \mathrm{~min}$ pyrrole, $4 \mathrm{~min}$ iodine and pyrrole, $6 \mathrm{~min}$ pyrrole and $4 \mathrm{~min}$ iodine and pyrrole.

\section{Fourier Transform Infrared Analysis (FT-IR)}

To know the chemical composition of the Ppy-I, was decided to perform an FT-IR, was prepared a potassium bromide $(\mathrm{KBr})$ pellet. $\mathrm{KBr}$ was placed in a standard mold for FT- IR with a pressure of 9 Tons / 5 min. The pellet was placed in the plasma reactor during the polymerization of the materials. Once polymerized was placed in the FT-IR scanning (Perkin Elmer).

\section{Cell cultures}

HepG2 (ATCC HB8065, USA) cell line derived from a human hepatoblastoma was obtained from the American Type Culture Collection (ATCC). The cells were cultured with Williams Media E (Gibco 12551, USA) supplemented with $10 \%$ of fetal bovine serum (FBS, Gibco 16000, USA), penicillin (100 units/ml Gibco 15240, USA) and streptomycin $(100 \mathrm{mg} / \mathrm{ml}, 15240$, USA). Cells were cultured in roller bottles (Nunc., USA) at $37^{\circ} \mathrm{C}, 5 \%$ of $\mathrm{CO}_{2}, 95 \%$ humidity. Media culture replacement was performed every 2 days for over a week. Cells were removed from the culture substrate by using trypsin and recultured every 7 days in a 1:3 proportion. 
Endothelial HUVEC cells (ATCC CRL 1730, USA) were obtained from the American Type Culture Collection (ATCC). The cells were seed in monolayers with D-MEM/F12K (Gibco 12634, USA) supplemented with 10\% FBS (Gibco 16000, USA), penicillin (100 units/ml 15240, USA), streptomycin (100mg/ml, 15240, USA), heparin (H4784 Sigma, USA) $0.1 \mathrm{mg} / \mathrm{ml}$ and Endothelial Cell Growth Supplement (ECGS E2759, SigmaAldrich, USA) $0.05 \mathrm{mg} / \mathrm{ml}$. Cells were cultured in roller bottles (Nunc., USA) at $37^{\circ} \mathrm{C}, 5 \%$ of $\mathrm{CO}_{2}, 95 \%$ humidity followed by a media culture replacement every 2 days for over a week. Cells were removed from the culture substrate by using trypsin and recultured every 7 days in a 1:3 proportion.

Cultured confluence was of $1 \times 10^{5}$ cells in all four scaffolds experiments: Hepatocytes were seeded on Ppy -I coated and uncoated scaffolds; for the next two seeding experiments a co-culture of HepG2 (80\%) - endothelial cells (20\%) was seeded on Ppy-I coated and uncoated scaffolds. To ensure scaffold cell anchoring, seeding was performed 4 hours prior each experiment as ATCC protocol recommendation. The scaffold with the hepatocytes was placed in the bioreactor (Figure 1) with a constant media culture flow rate of $7 \mathrm{ml} / \mathrm{min}$. Cellular confluence was assayed by taking a media culture sample $(8 \mathrm{ml})$. To assure the uniform cellular distribution the scaffold seeding was opposite depending on the cell type, thus preventing punctual cellular distribution. Once seeded the scaffolds were rolled up on the bioreactor central support, avoiding sponge stretching or surface deformation allowing media culture
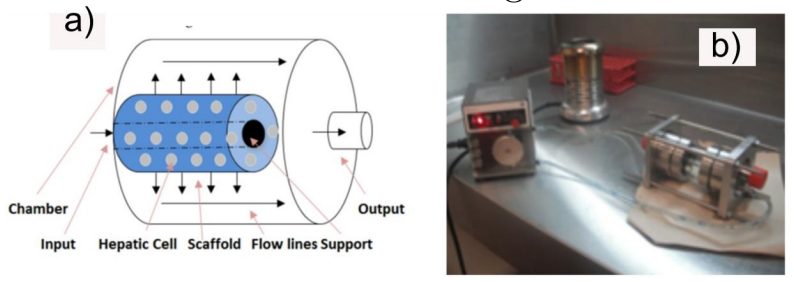

Figure 1. Construction and RFB placement inside the $\mathrm{CO}_{2}$ incubator. free flow and correct circulation through the scaffold. Once the scaffold is rolled up the glass chamber is placed horizontally to hold up the sponge and the central support (Figure $1)$.

Was used media culture specific for hepatocytes and endothelial cells in a 50\%$50 \%$ proportion during the first 15 days that was supplemented with 10\% FBS for the first 8 days of the culture. Cell density, albumin production and total proteins secretion was assayed after 21 days of culture.

\section{Total protein quantification}

Total protein secretion was measured every $24 \mathrm{~h}$ for the last 7 days of culture by using the bicinchoninic acid kit (BCA, ThermoScientific; cat. 23255, USA). The kit is based in colorimetric detection $(562 \mathrm{~nm})$. The standard curve was initially obtained using bovine serum albumin (BSA) at different concentrations following the manufactures' recommendation. The samples $(0.5 \mathrm{ml})$ were taken from the RFB exit compartment once a day, and were centrifuged $(15,000 \mathrm{rpm})$ prior to protein detection. The samples were then placed in 96 well plate to be measured in a multimodal DTX 880 detector (BeckmanCoulter, Germany). The experiment was performed by triplicate

\section{Albumin quantification}

Albumin quantification was measured every $24 \mathrm{~h}$ for the last 7 days of culture by using an Elisa test (AssayproEA2201-1, USA). This assay is based in colorimetric detection $(450 \mathrm{~nm})$. The samples $(0.5 \mathrm{ml})$ were taken from the RFB exit compartment once a day, and were centrifuged (15,000 rpm) prior to protein detection. The samples were then placed in 96 well plates to be measured in a multimodal DTX 880 detector (BeckmanCoulter, Germany). The experiment was performed by triplicate 


\section{System description}

The RFB inside $\mathrm{CO}_{2}$ incubator was connected to a peristaltic pump through polyurethane lines that were inserted through small holes to the incubator door. The length of the lines outside the incubator $\mathrm{CO}_{2}$ was $15 \mathrm{~cm} /$ each, while inside the incubator was $50 \mathrm{~cm}$. A $55 \mathrm{~cm}$ hose was used indoors due culture media flow thermic equilibrium $\left(37^{\circ} \mathrm{C}\right)$ before entering the bioreactor (Fig. 2).

Then the cell culture was performed using the RFB to compare the cell density, the secretion of albumin and total protein in culture and when co-cultured on a non-coated Ppy-I coated scaffold. Cell density of $1 \times 10^{5}$ $\mathrm{ml}^{-1}$ HepG2 was used for monoculture cells and $0.8 \times 10^{5} \mathrm{ml}^{-1} \mathrm{HepG} 2$ cells and $0.2 \times 10^{5}$ cells $\mathrm{ml}^{-1}$ HUVEC cells when co-cultured. Dimensions for the Ppy-I coated PLLA and non-coated scaffolds were $6 \mathrm{~cm}$ long, $2.5 \mathrm{~cm}$ wide and $0.5 \mathrm{~cm}$ deep; on which the cells were seeded in six points equally spaced on the surface of the scaffold. HUVEC cells were placed directly at the exit of the RFB, while hepatocytes were placed far inside of it. The scaffolds were rolled up onto the main bracket RFB to cover all the possible media culture outlets (Fig. 2), $80 \mathrm{ml}$ of culture medium was used for 21 days in a $\mathrm{CO}_{2}$ incubator.

\section{Immunofluorescence}

To address cell distribution inside the RFB was assayed anti-human VWF (clotting factor VIII 1:25) by using immunofluorescence (Dako, Denmark) for HUVEC cells. Nuclei were stained with Hoechst 33342 dye. Samples were washed with PBS (5x). Cells were observed with a Carl Zeiss confocal microscope (LSM 780 Axio Observer) and analyzed with Zen 2011 and ImageJ softwares. Images were randomly taken in different zones on the scaffolds to assess the uniform cell distribution.

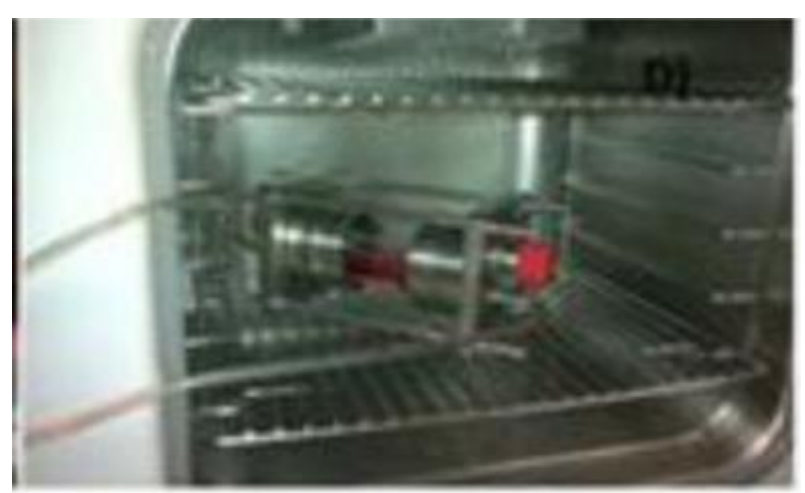

Figure 2. a) Radial flow bioreactor schematic and b) RFB assembled with the peristaltic pump.

\section{Scanning Electron Microscopy (SEM)}

The cultured scaffolds are drained of their media cell culture and immediately placed in the appropriate fixative for a minimum of an hour. The fixative routinely used in this lab is a modified Karnovsky's, 4\% Paraformaldehyde and 25\% Glutaraldehyde (Sigma-Aldrich, USA) in 0.1M Phosphate Buffer. After fixation the scaffolds are rinsed several times with phosphate buffered saline (PBS) (Invitrogen, USA) followed by post fixation with $1 \%$ osmium tetroxide in phosphate buffer for one hour. After rinsing again with PBS for 15 minutes, the scaffolds were dehydrated through a series of graded ethyl alcohols: $70 \%$ for $10 \mathrm{~min}$., $95 \%$ for 10 min. and three changes of $100 \%$ for 5 minutes each. All the SEM images were taken with the microscopy JEOL, JSM-5900 LV model.

\section{Data analysis}

Data were reported as mean $\pm \mathrm{SEM}$ for at least three independent experiments carried out by triplicate. The Origin package version 8.1 was used for statistical analysis. Comparison among groups was done by means of ANOVA. Tukey's method was used for multiple comparisons. A $\mathrm{p}<0.05$ was considered as statistically significant. 

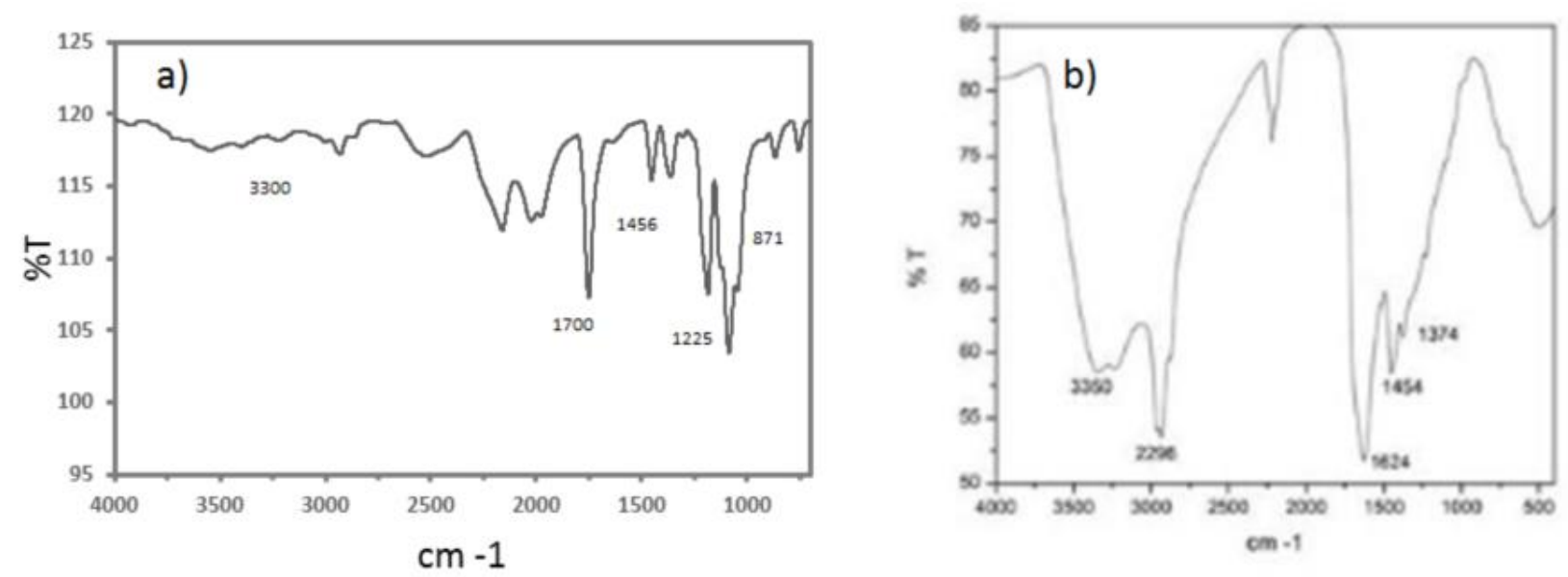

Figure 3. FT-IR a) spectrum in control scaffold, b) spectrum in Ppy-I coated scaffold.

\section{RESULTS}

\section{Coated PLLA scaffolds analysis}

FT-IR spectrum for PLLA scaffolds (3a) shows a $\mathrm{OH}$ peak at $3300 \mathrm{~cm}^{-1}$, the carbonyl group at $1700 \mathrm{~cm}^{-1}$, the methyl group at $1456 \mathrm{~cm}^{-1}$, the $\mathrm{C}-\mathrm{O}$ appears at $1225 \mathrm{~cm}^{-1}$ and at $871 \mathrm{~cm}-1$ appears the $\mathrm{c}-\mathrm{c}$ groups. The coated sample spectrum (3b) shows the Ppy-I chemical structure and composition, the vibration at $3350 \mathrm{~cm}^{-1}$ are amines, aliphatic carbons at $2964 \mathrm{~cm}^{-1}$, the nitrile groups at $2200 \mathrm{~cm}^{-1}$, and at $1624 \mathrm{~cm}^{-1}$ the pyrrole rings. The read shows the component molecules complexity; was suggested these chemical group complexity increases adhesion and cell proliferation in culture.

Scaffold SEM images (Figure 4) were taken before (a) and after (b) plasma discharge modification showing no important modifications regarding pore size or fiber diameter.

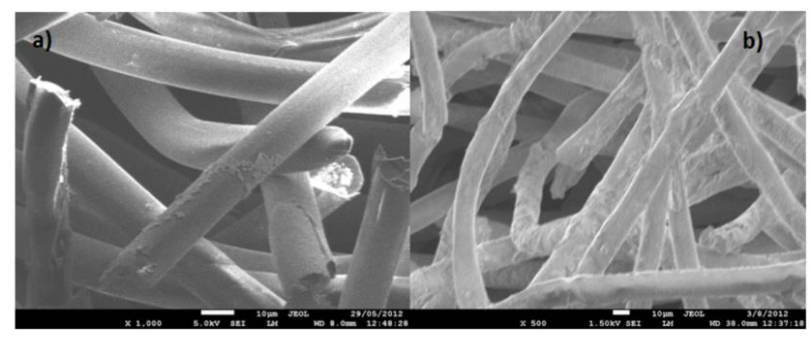

Figure 4. SEM images a) PLLA scaffold and b) PLLA/Ppy-I coated scaffold (Scale bar 50 micrometers, 100x).

\section{Cultured Cells (21 Days)}

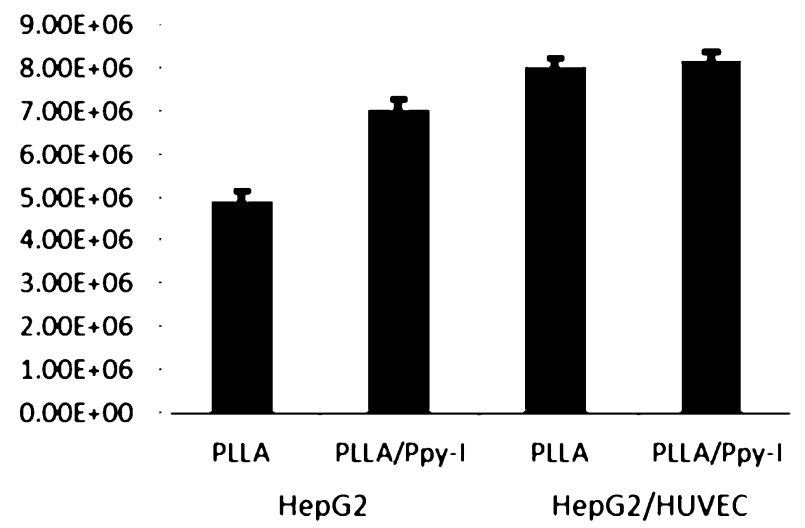

Figure 5. Hepatocytes (monoculture) and hepatocytes/endothelial (co-culture) cells in RFB cell density.

Was observed an increase sample rigidity when placed inside the bioreactor as a mechanical difference after plasma discharge modification.

\section{Seeded cells on the coated scaffolds}

Cell density $\left(1 \times 10^{5}\right.$ cells $\left./ \mathrm{mL}\right)$ was equal regardless the cell type and was measured after 21 days on culture, for all the experimental conditions (Fig. 5). Coatedbioreactor HepG2 culture, showed a higher cellular density $\left(6.94 \times 10^{6}\right.$ cells $\left./ \mathrm{mL}\right)$ than the control $\left(4.88 \times 10^{6}\right.$ cells $\left./ \mathrm{mL}\right)$ scaffold. Cell proliferation increases ìn the co-culture with endothelial cells by $61 \%$, and 7.89 $\times 10^{6}$ cells $/ \mathrm{mL}$ than control; and $8.03 \times 10^{6}$ cells $/ \mathrm{mL}$ in the Ppy-I coated scaffold. 
Monoculture SEM images (Figure 6) shows the scaffolds fibers(a), (solid lines) with cells, displayed as small polygons around the surface of the fibers; on scaffolds-coated fibers, the cells form clusters, wrapping the fiber surface in addition to the laminar cell growth.

Co-culture micrographs show cell distribution on the PLLA scaffold (Figure 7). The clusters are conformed of HepG2 cell while resting on an HUVEC layer around the surface of the fibers. High rate of cell proliferation is related to the distribution displayed. Coated-scaffold cellular distribution is shown as a continuous sheet that is mostly formed by HUVEC cells (7b) wrapping around the fiber scaffolds, thus indicating good cell adhesion to the fibers.
HepG2 cells formed bigger cluster when compared to the non-coated scaffold. It is likely that the Ppy-I surface modification on the scaffold, favors cell adhesion as previously described (Ramirez-Fernandez, 2012).

Figure 8 shows confocal microscopy HepG2 nuclei (blue) trace the exact distribution in the scaffolds after 21 days of culture inside the bioreactor. (a) Distribution is scattered and discontinuous through the scaffold, (b) cell clusters are also scattered around the fibers and through the scaffold which surface is visible, (c) Disperse cell clusters are seen on the PLLA/Ppy-I scaffold, (d) The PLLA/Ppy-I scaffold shows an increased number of nuclei along the fibers, the later could be associated with increased cellular-fiber anchorage.
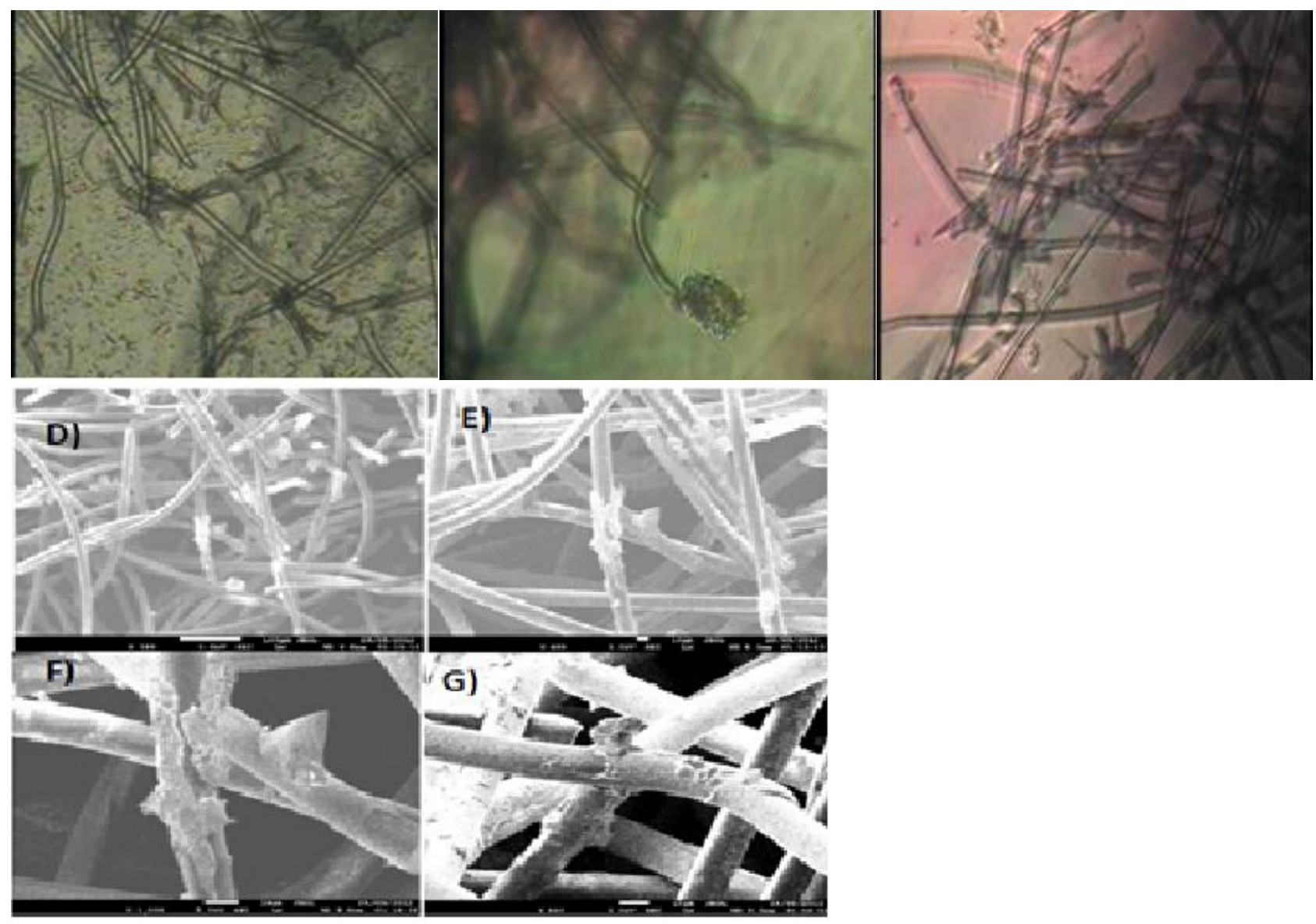

Figure 6. (a) HepG2 cells after 21 days of culture on PLLA scaffold inside the RFB (b) HepG2 cells after 21 days of culture on non-coated scaffold inside the RFB SEM images. The normal physiology of HepG2 cell is marked with a circle. (Scale bar 20 micrometers, $200 \times$ ). 

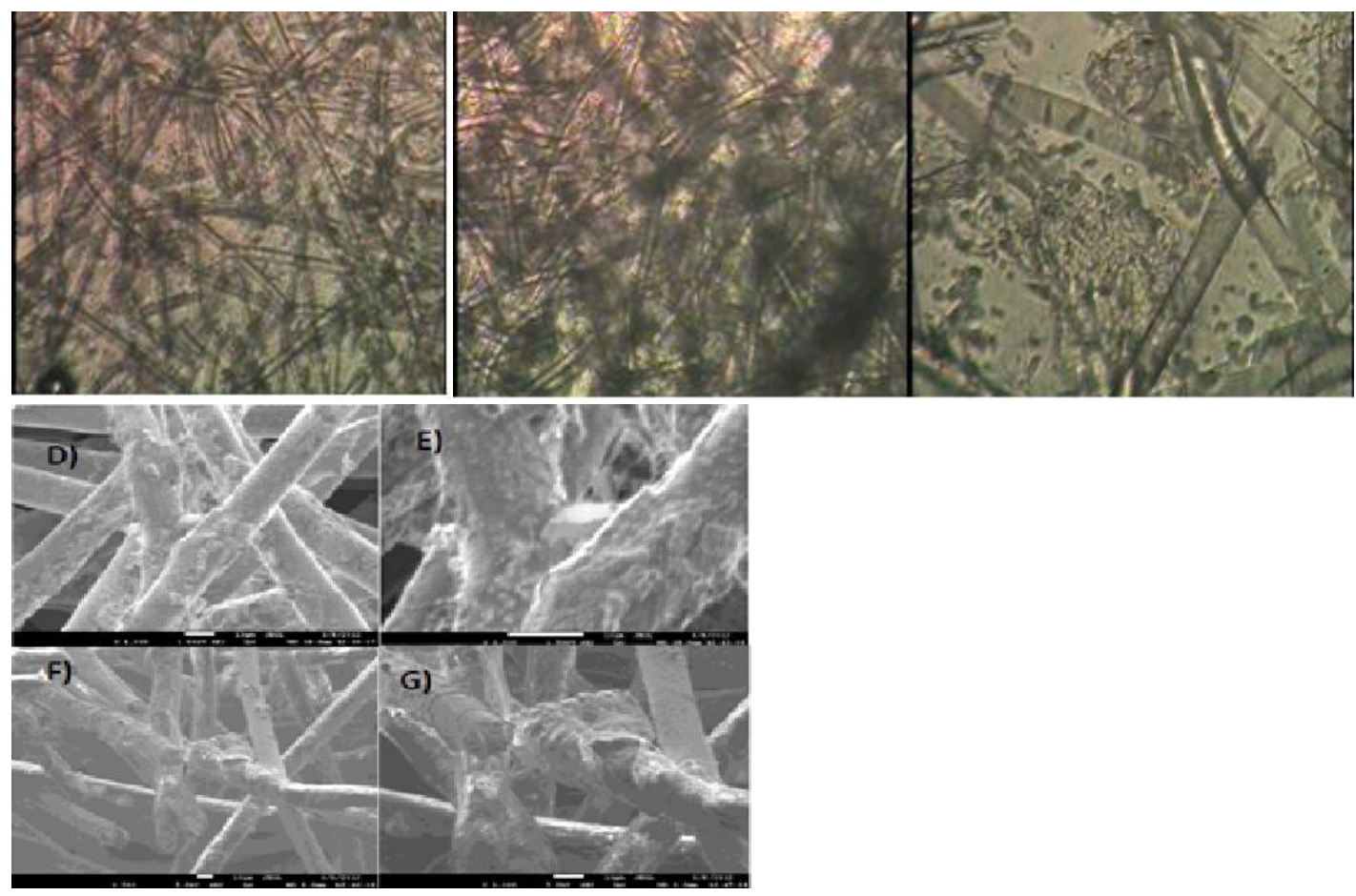

Figure 7. HUVEC and HepG2 cells after 21 days of culture on PLLA scaffold inside the RFB (b) HepG2 cells after 21 days of culture on non-coated scaffold inside the RFB SEM images. The normal physiology of HUVEC cells in 3D culture is marked with a rectangle. (Scale bar 20 micrometers, $200 \times$ ).

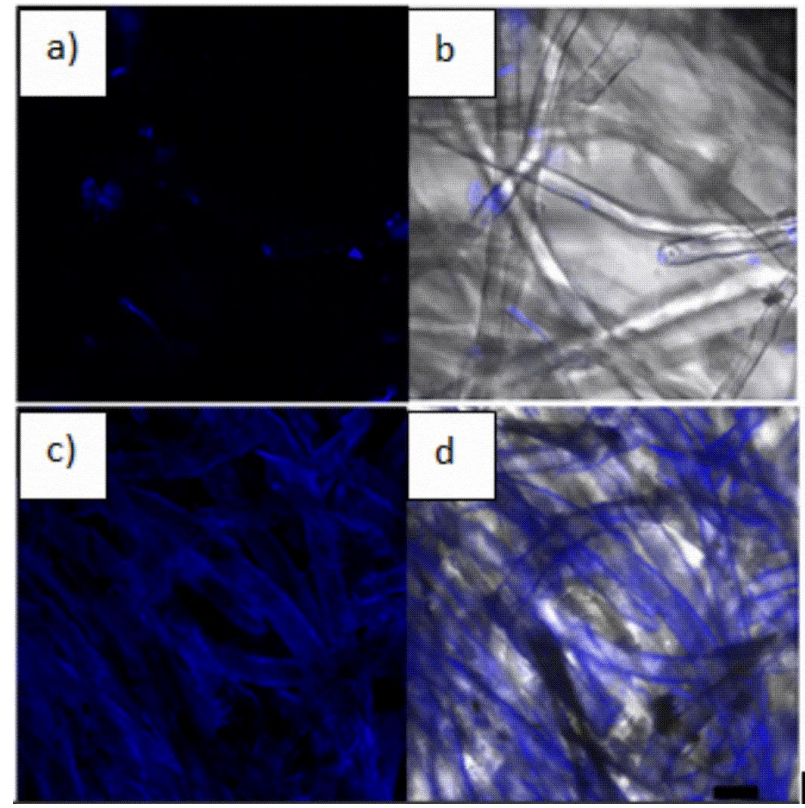

Figure 8. (a) PLLA scaffold HepG2 cells culture, (b) light field microscopy composite with cells location; (c) PLLA/PPy-I Scaffold HepG2 cells culture, (d) HepG2 cells in light field microscopy composite with cells localization. (Scale bar 20 micrometers, $200 \times$, Hoestsch nuclei staining).
Figure 9 shows HepG2 and HUVEC cells distribution on the scaffold after 21 culture days. (a) HUVEC and HepG2 distribution are covering uniformly the whole surface of the scaffold, (b) HUVEC membranes (red) are only visualized wrapped on the scaffold fibers, (c) cell clusters are shown scattered along the fiber section, (d) PLLA scaffold / Ppy-I coated culture shows only proliferation on the fiber section, (e, f) HUVEC cells are also seen in the same area (figs. 9 e-f). Both cell types are proliferating as a normal 3D culture.

\section{Total protein and albumin quantification}

To compare the hepatocytes' metabolic activity between monoculture and co-culture with the endothelial cells seeded on the different scaffolds, was measured the total protein in the supernatant; our result shows an increase in total protein $6.5 \mathrm{ug} / \mathrm{ml}$ on the non-coated scaffold and $7 \mathrm{ug} / \mathrm{ml}$ on the coated scaffold. 


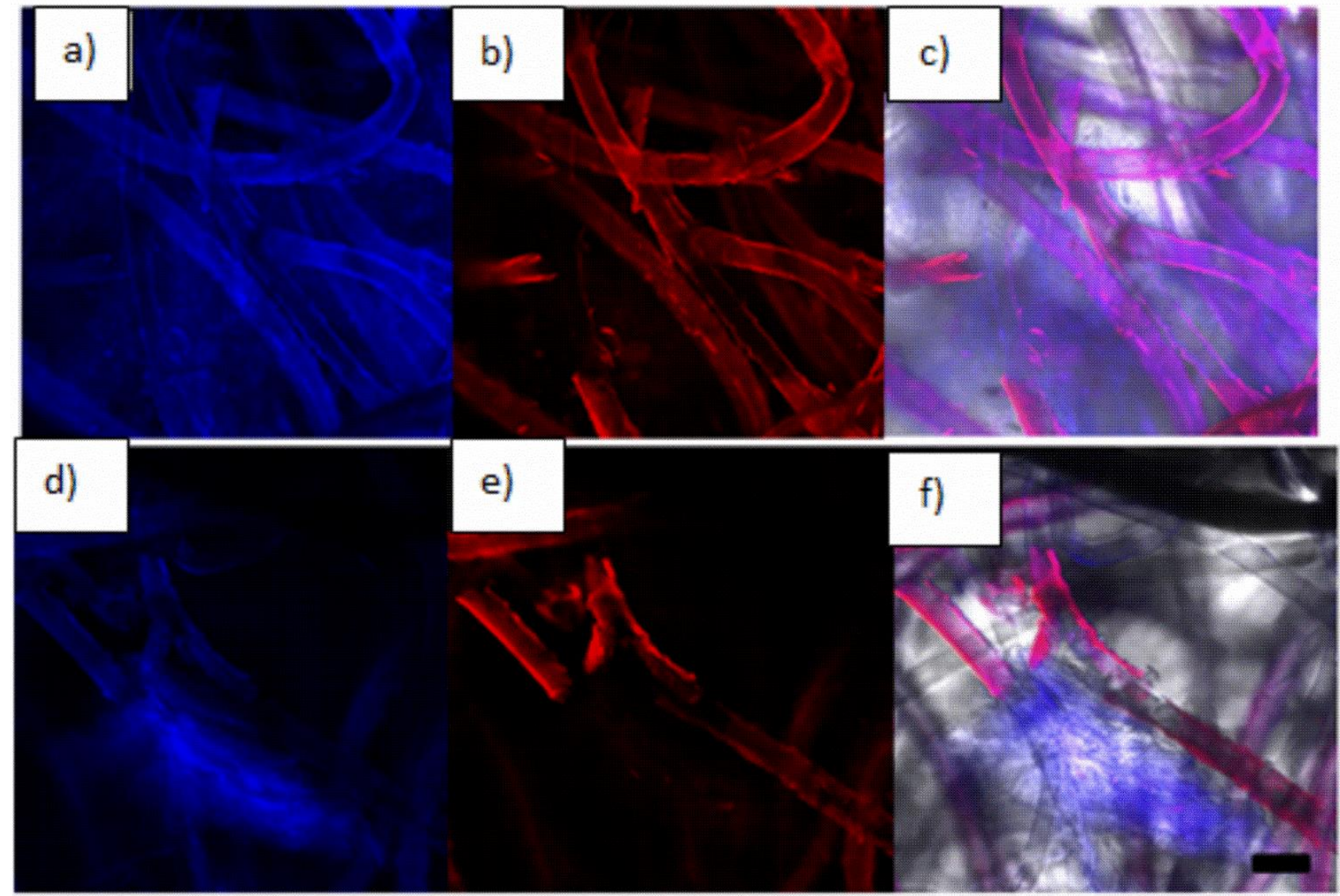

Figure 9. (a) PLLA scaffold HepG2 and HUVEC culture, (b) PLLA scaffold detection of human anti-vWF immunofluorescence, (c) light field microscopy composite with cells location, (d) PLLA/Ppy-I coated Scaffold HepG2 and HUVEC culture, (e) PLLA/Ppy-I coated scaffold human anti-vWF immunofluorescence (f) light field microscopy composite with cells location. (Scale bar 20 micra, 200×).
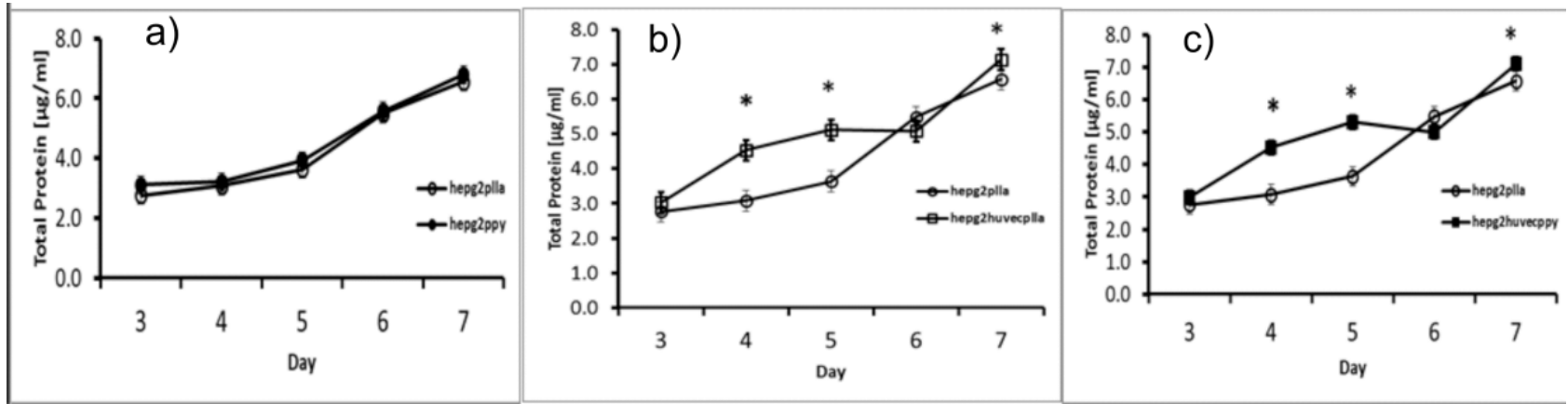

Figure 10. Total Protein content a) PLLA scaffold HepG2 culture (white circles) and PLLA/Ppy-I coated HepG2 culture (black circles), b) PLLA scaffold HepG2 culture (white circles) and PLLA scaffold HepG2/HUVEC culture (white squares), c) PLLA scaffold HepG2 culture (white circles) and PLLA/Ppy-I scaffold HepG2/HUVEC culture(black squares) $(* \mathrm{p}<0.05)$.

To measure the metabolic activity, total albumin secretion was assay on media culture supernatant, obtaining similar data than in the total protein content. There was an increase of $40 \%$ albumin on control scaffold $(0.210 \mathrm{mg} / \mathrm{ml})$ compared with the hybrid scaffold $(0.275 \mathrm{mg} / \mathrm{ml})(\mathrm{p}<0.05, \mathrm{n}=3)$ (Figure 11). PLLA / Ppy-I coated scaffold with HepG2 culture shown an increasing albumin content along 7 days of culture, 

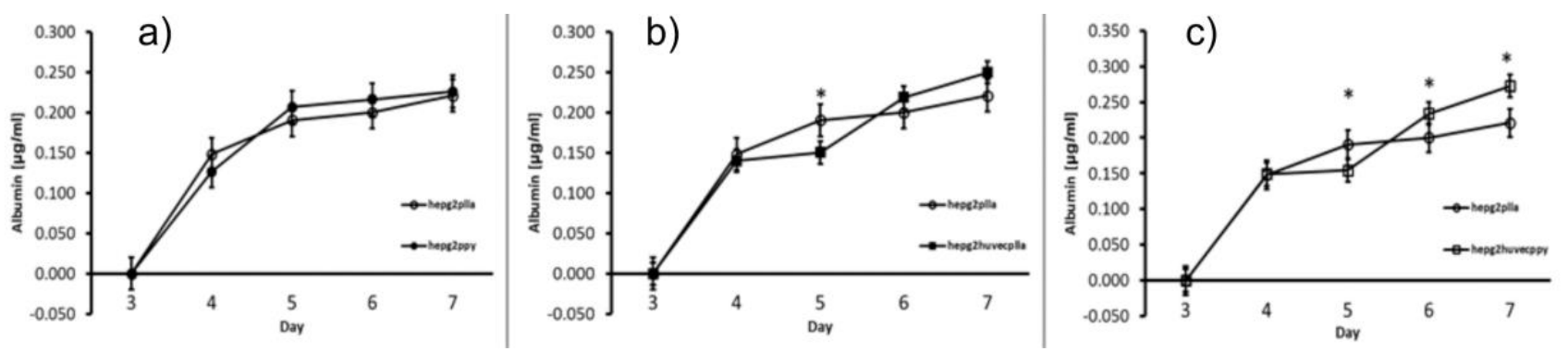

Figure 11. Albumin content in media culture, a) PLLA scaffold HepG2 culture (white circles) and PLLA/Ppy-I coated scaffold HepG2 culture(black circles), b) PLLA scaffold HepG2 culture (white circles) and PLLA scaffold HepG2/HUVEC culture (black squares), c) PLLA scaffold HepG2 culture(white circles) and PLLA/Ppy-I coated scaffold HepG2/HUVEC culture (white squares) $(* \mathrm{p}<0.05)$.

resulting in no difference when compared with the co-culture.

\section{DISCUSSION}

HepG2/HUVEC co-culture is necessary to improve proliferation and metabolic rates inside a RFB, thus increase culture time with no physiological damage for the cells (Baudoin, 2011).

Fig. 3 shown the surface chemical composition of PLLA and PLLA/Ppy-I. As shown on the Ppy-I coated scaffold, it presents extra functional groups on the surface against the control scaffold. These groups interact with the cellular membrane and allowing a better anchorage and cell proliferation (Cruz, 1999; Zuñiga-Aguilar, 2014).

Anchorage and cellular proliferation are based on the successful interaction and communication between organelles and thus cells. It is necessary, that there is no chances for the cells to float on the media culture (Grabenbauer, 2000). This is the reason why we considered that the cells in the supernatant are insignificant. As shown on figure (9f) cells form clusters around the fibers before to be found in the supernatant.

Apatite or cellulose fibers and porous biopolymeric materials are the two most used for a RFB, fibers are generally packaged in RFB where cells proliferate. Polymeric materials in the other hand allow cell cluster formation in the RFB (Ishii, 2008).
Materials used for bioreactor construction were carefully selected due its cell and protein non-adhesion properties. The bioreactor chamber was also built by using Pyrex glass and pyrogenic silica lines also used for cellular culture, thus unattached cells can circulate through the sponge and attach to it due media culture flow of $7 \mathrm{ml} / \mathrm{min}$, that is necessary to effective media culture exchange on the scaffold (Pasirayi,2011).

PLLA polymer was selected due its mechanical characteristics such as softness and easy Ppy-I modification process that maintains the size and the shape of the pores. In combination PLLA / Ppy-I surfaces allow hepatocytes proliferation, cluster formation and perform its normal metabolic functions.

Hepatocytes and endothelial cell coculture are more efficient when seeded as a monolayer (Ramirez-Fernandez, 2012), and the later can be assessed by the cluster formation that could be affected by nutrients and oxygen supply and the efficiency to remove waste products (Thomas, 2006).

Inside a common bioreactor cell proliferation rates as well as cluster formation increases when cells are seeded on coatedscaffolds, but this increase is even higher (10 times) if a RFB is used (Yamashita, 2002). HepG2/HUVEC culture forms a well-organized tissue-like architecture that resembles liver histology. HUVEC cells layers adhere to the fibers building a matrix where hepatocytes rely on (Inamori, 2009). The parenchymal proliferation in our bioreactor 
increase about $40 \%$ against our control experiment. We need to enhance our experiment design to get the $60 \%$ reported in other bioreactors (Katayama, 2013).

As shown on the SEM images, HUVEC cells generate a thin layer on the scaffold lining that mimics the vascular physiological architecture. We could address these data by confocal microscopy and the production of endothelial source clotting factors VIII, shown in red color (Risdub, 2003).

There was also an increase in the total protein secretion measured on the media culture on Ppy-I coated scaffold in the presence of Ppy -I when compared with the non-coated scaffold. Albumin secretion to the media was also assessed and the results showed similar results (Figure 11). To minimize the effect of the fetal bovine (FBS) on total protein production all samples were compared with the FBS as the control simple, this could be why the protein secretion values show are minimal (Kataoka, 2005).

The increase in cell proliferation on 3D culture with hybrid scaffold could be explained by the hepatocyte interactions with endothelial cells; that may increase the nutrient intake, metabolite synthesis and an effective cell detoxification. With a hepatocyte culture on a bioreactor allows a three-dimensional cell culture but is surpassed in cell proliferation and metabolic activity, by using a hybrid cell scaffold.

Our bioreactor design allows cell proliferation and their correct development and metabolic functionality in the same culture, it represent an improving over other bioreactors that use an already seeded scaffold to be inserted inside the bioreactor. A critical consideration when used bioreactors clinically is the need to maintain cell cultures at high density, feature that increases metabolic cell rate. Thus our data suggest that Ppy-I modified scaffolds represent a better platform for hepatocytes and endothelial cells co-cultures could greatly contribute for a bio-artificial liver high- performance.

\section{CONCLUSION}

In co-culture with HUVEC cells, hepatocytes (HepG2) increase their proliferation and are able to form spheroids-shape colonies more efficiently than on a monoculture scaffold. This culture also showed an albumin secretion increase even without the scaffold surface modification according with the value data obtained. These data suggest that endothelial/hepatocyte co-culture seeded on a PLLA / Ppy-I modified scaffold may be a promising therapeutic strategy for chronic liver diseases.

\section{Acknowledgments}

The authors thank the Universidad Autonoma Metropolitana (UAM), Consejo Nacional de Ciencia y Tecnologia (CONACYT) (project 155239) and the Instituto de Ciencia Y Tecnologia Del D.F. (ICyT-DF) (PIUTE 10-63276/2010) y (PICSA 11-14/2011), for their collaboration on the present work.

\section{REFERENCES}

1. Carpentier B., Gautier A., Legallais C. (2009) "Artificial and bioartificial liver devices: present and future," Gut; 58:1690-1702.

2. McKenzie T., Lillegard J. B., Nyberg S.L. (2008) "Artificial and Bioartificial Liver Support," Semin Liver Dis; 28(2): 210-217.

3. Zheng Z., Li X., Li X., Ma X. (2013) "Artificial and bioartificial liver support systems for acute and acute-on-chronic hepatic failure: A meta-analysis and meta-regression," Experimental And Therapeutic Medicine 6: 929-936. 
4. Wang Y, Susando T, Lei X, (2010) "Current development of bioreactors for extracorporeal bioartificial liver (Review)," Biointerphases 5: FA116?FA131.

5. Galbusera F., Cioffi, M., Raimondi M., and Pietrabissa R. (2007) "Computational modeling of combined cell population dynamics and oxygen transport in engineered tissue subject to interstitial perfusion," Comput Methods Biomech Biomed Engin.; 10: 279-287.

6. Pampaloni F., Reynauld E., Stelzer E. (2007) "The third dimension bridges the gap between cell culture and live tissue," Nature Reviews Molecular Cell Biology 8, 839-845.

7. Park, J., Li, Y., Berthiaume, F., Toner, M., Yarmush, M. L. and Tilles, A. W. (2008) "Radial flow hepatocyte bioreactor using stacked microfabricated grooved substrates," BiotechnolBioeng.; 99(2), 455-467.

8. Chen X. B., Li M. G., and Ke H. (2008) "Modeling of the Flow Rate in the Dispensing-Based process for Fabricating Tissue Scaffolds," J. Manuf. Sci. Eng.; 130: 210031-7.

9. Ishii Y., Saito R., Marushima H., Ito R., Sakamoto T., Yanaga K., (2008) "Hepatic reconstruction from fetal porcine liver cells using a radial flow bioreactor," World J Gastroenterol; 14(17): 2740-2747.

10. Du Y, Han R, Wen F, Ng San San S, Xia L, Wohland T, Leo HL, Yu H. (2008) "Synthetic sandwich culture of 3D hepatocyte monolayer," Biomaterials.; 29(3):290-301.

11. Li M.G., Tian X.Y. and Chen X.B. (2009) "Modeling of Flow Rate, Pore
Size, and Porosity for the DispensingBased Tissue Scaffolds Fabrication," J. Manuf. Sci. Eng.; 131:034501.

12. Li M.G.,Tian X.Y. and Chen X.B. (2009) "A brief review of dis-pensingbased rapid prototyping techniques in tissue scaffold fabrication: role of modeling on scaffold properties prediction," Biofabrication; 1: 032001.

13. Kakinoki S., Yamaoka T., (2014) "Thermoresponsive elastin/laminin mimicking artificial protein for modifying PLLA scaffolds in nerve regeneration," J. Mater. Chem. B, 2: 5061

14. Cruz G.J, Morales J, Olayo R (1999) "Films obtained by plasma polymerization of pyrrole," Thin Solid Films 342( 1-2), 26: 119-126

15. Zuñiga-Aguilar E., Godinez R., Ramirez-Fernandez O., Morales J., Olayo R. (2013) "Development of a Neuromuscular Junction Model on Surfaces Modified by Plasma Polymerization," Revista Mexicana de Ingeniería Biomédica; 34:3.

16. Olayo R, Ríos C, Salgado-Ceballos H, Morales J. (2008) "Tissue spinal cord response in rats after implants of polypirrole and polyethylene glycol obtained by plasma," J. Mater. Sci.: Mater. Med.;19: 817-826.

17. Dhillon A, Kaura A, Srivastavab AK, Avasthic DK. (2010) "Experimental investigations of semicrystalline plasma polymerized polypyrrole for surface coating," Prog Org Coat.; 69; 396-401.

18. Ramirez-Fernandez O., Godinez R., Morales J., Gomez-Quiroz L., Gutierrez-Ruiz M.C., Zuñiga-Aguilar E., Olayo R. (2014) "Plasma gradient modified scaffolds to generate a chemoattractant surface," Superficies y Vacío; 27(1): 20-23. 
19. Zhang J, Wu MZ, Pu TS, Zhang ZY, Jin RP, Tong ZS, Zhu DZ, Cao DX, Zhu FY, Cao JQ. (1997) "Investigation of the plasma polymer deposited from pyrrole," Thin Solid Films.;307:14-20.

20. Wang J, Neoh KG, Kang ET. (2004) "Comparative study of chemically synthesized and plasma polymerized pyrrole and thiophene thin ?lms," Thin Solid Films.;446:205-217

21. Cruz JG, Mondragón-Lozano G, DíazRuiz A, Manjarrez J, Olayo R, SalgadoCeballos H, Olayo MG, Morales J, Alvarez-Mejía L, Morales A, MéndezArmenta M, Plascencia N, Fernández M, Ríos C (2012). "Plasma polypyrrole implants recover motor function in rats after spinal cord transection," J. Mater. Sci.: Mater. Med.;23:2583-2592.

22. Zuñiga-Aguilar E., Olayo R., RamírezFernández O., Morales J., Godínez R. (2014) "Nerve cells culture from lumbar spinal cord on surfaces modified by plasma pyrrole polymerization," Journal of Biomaterials Science, Polymer Edition, 255(7): 729-747.

23. Ramirez-Fernandez O., Godinez R., Morales J., Gomez-Quiroz L., Gutierrez-Ruiz M.C., Zuñiga-Aguilar E., Olayo R. (2012) "Superficies Modificadas Mediante Polimerización por Plasma para Cocultivos de Modelos Hepaticos," Revista Mexicana de Ingeniería Biomédica; 33:2.

24. Thomas RJ, Bennett A, Thomson B, and Shakesheff KM. (2006) "Hepatic stellate cells on poly (DL- lactic acid) surfaces control the formation of 3D hepatocytes co-culture aggregates in vitro," Eur Cell Mater.; 11:16- 26.

25. Inamori M., Mizumoto H., Kajiwara T., (2009) "An Approach for Formation of Vascularized Liver Tissue by Endothelial Cell-Covered
Hepatocyte Spheroid Integration," Tissue Engineering Part A. 15(8): 20292037.

26. Risbud M.V., Karamuk E., Moser R., Mayer J. (2003) "Hydrogel-Coated Textile Scaffolds as Three-Dimensional Growth Support for Human Umbilical Vein Endothelial Cells (HUVECs): Possibilities as Coculture System in Liver Tissue Engineering," Cell Transplantation, 11(4):369-377.

27. Werner A, Duvar S, Muthing J, et al. (2000) "Cultivation of immortalized human hepatocytes HepZ on macroporous CultiSpher G microcarriers," Biotechnol Bioeng. ;68(1):59-70.

28. Yamashita Y, Shimada M, Ijima H, et al. (2002) "Hybrid-artificial liver support system," Surgery. 131:334-340.

29. Baudoin R., Griscom L., Prot J., Legallais C., Leclerc E. (2011) "Behaviour of HepG2/C3A cell cultures in a microfluidic bioreactor," Biochem Eng J; 53(2):172-181

30. Grabenbauer M1, Sätzler K, Baumgart E, Fahimi HD. (2000) "Three dimensional ultrastructural analysis of peroxisomes in HepG2 Cells," Cell Biochemistry and Biophysics, 32(13):37-49

31. Pasirayi G., Auger V., Scott S., Rahman P., Islam M., O'Hare L., Ali Z. (2011) "Microfluidic bioreactors for cell culturing: a review," Micro and nanosystems, (3):137-160

32. Kataoka K., Nagao Y., Nukui T., Akiyama I., Tsuru K.,Hayakawa S., Osaka A., Huh N., (2005) "An organic-inorganic hybrid scaffold for the culture of HpG2 cell in bioreactor," Biomaterials, 26(15):2509-251 
33. Katayama A., Arano T., Sato T., Ikada Y., Yoshinari M. (2013) "Radial-Flow Bioreactor Enables Uniform Proliferation of Human
Mesenchymal Stem Cells Throughout a Three-Dimensional Scaffold," Tissue Engineering Part C: Methods. 19(2): 109-116. 
